\title{
Finding Alternative Methods for Controlling the Power Shortage in Kurdistan through Improving Buildings' Energy Performance
}

\author{
Kawar Tahseen Salih \\ Research Center, Duhok Polytechnic University, Kurdistan Region-Iraq
}

\section{ABSTRACT}

The power shortage is one of the major problems in developing countries. Kurdistan Region of Iraq suffers from this issue, like other developing countries. Especially, after the economy crises that has started in 2014. However, all its efforts for tackling this challenge has been in providing more energy supply stations and more fuel provision. Few studies have been found in the region that seek the relation between the quality of buildings and energy consumption. It is questioned if the building sector in Kurdistan is well managed and environmentally sufficient to consume minimum amount of energy since it is the largest energy consuming sector. This research will seek an alternative to decrease the energy demand in buildings instead of expanding the energy sector. This could be achieved by evaluating the quality of building sector environmentally and improving it. Providing guidelines for building's thermal regulations, passive building design and increasing the energy efficiency of buildings by renewal means could be alternative strategies for lowering the energy consumption. Theoretical and numerical research approach have been taken in to account for finding the answer through a case study and comparative analysis. A variation of $21-29 \%$ of power consumption can be observed between buildings that have not considered energy efficiency criteria in their design and those who reflected them more in the design.

KEYWORDS : Energy consumption, Energy efficient buildings, Shape compactness, Building orientation, Building thermal insulation.

\section{INTRODUCTION}

The increment of the demand for energy has become a global issue with the growing of both population and per capita energy consumption in the world. In 2012 and 2013, the global power consumption continued to increase by $2.3 \%$ (Sorrell, 2015). The growth of the demand for energy is not only limited to the developed countries. Developing countries on the other hand, have started producing more power to fulfill their needs. In Kurdistan region, the demand increased dramatically in the last two decades. It started to rise the energy production from nearly $350 \mathrm{MW}$ in

Academic Journal of Nawroz University (AJNU)

Volume 7, No 4 (2018).

Regular research paper : Published 21 December 2018

Corresponding author's e-mail : kawar.salih@dpu.edu.krd

Copyright (C2017 Kawar Tahseen Salih.

This is an open access article distributed under the Creative Commons Attribution License.
2004 to 2500 MW by 2013 (Kurdistan Ministry of Electricity, 2014)(Fig.1). However, after the economy crises in 2014, and the austerity policy, this production has become lower while the energy demand grew steady. Therefore, Kurdistan needs to tackle the issue through alternatives.

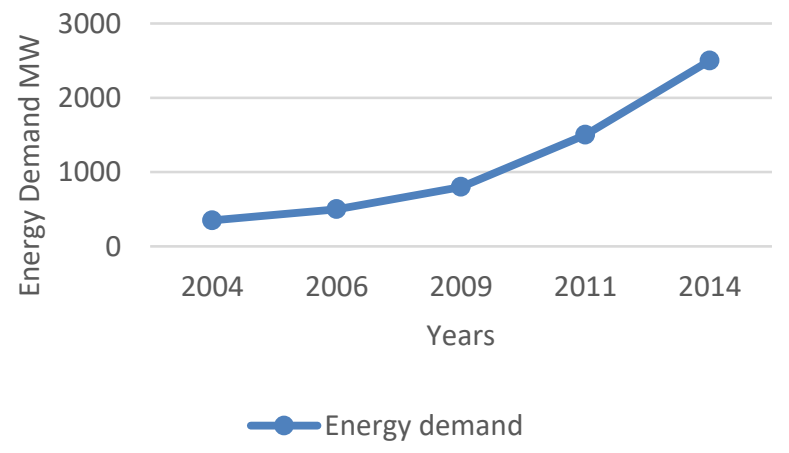

Fig (1) : Increment of energy demand in Kurdistan (2004-2014) (Kurdistan Ministry of Electricity, 2014)

One alternative widely studied and applied in developed countries is improving efficiency and 
reducing energy demand. Buildings are designed to consume less energy, since building sector consumes most of the produced power according to the recent studies. Strategies for decreasing energy consumption in building sectors will be elaborated in this paper. Residential sector consumes the most supplied power in Kurdistan. According to the data of General Directorate of Duhok Electricity (2016), 78\% of power in Kurdistan is supplied for the residential sector, $9 \%$ for commercial, $9 \%$ for government buildings, and the rest is spent for the industrial and agricultural buildings. Therefore, the focus must be concentrated on residential sector (Fig.2).

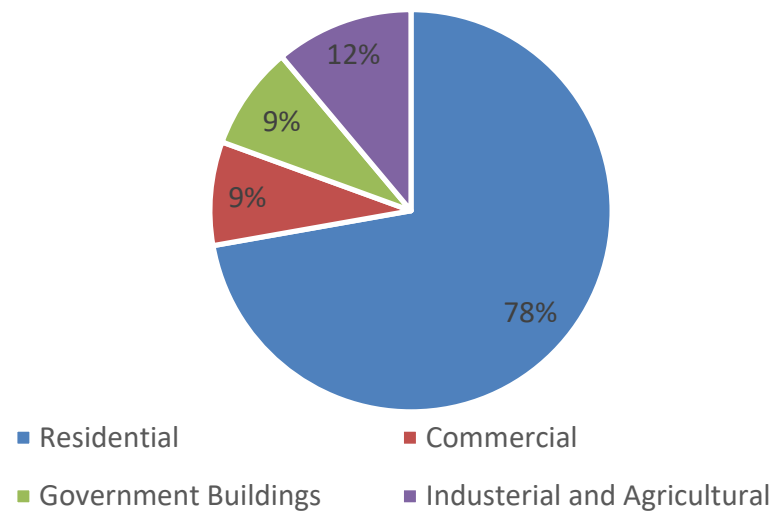

Fig (2) : Percentage of Energy consumption in different sectors in Duhok (General Directorate of Duhok Electricity, 2016)

\section{HEATING AND COOLING IN BUILDINGS AS A MAIN ISSUE}

Heating and cooling consume most of the energy in the residential sector. The demand for energy in Kurdistan during the cold and hot seasons reaches the highest levels because of the heating and cooling in buildings. For instance, in Duhok the demand of energy during
December and January is more than double of the energy demand in spring and fall. Because, the air temperature during April, May, September and October is in the thermal comfort level where no heating or cooling requires for buildings (Fig.3). As stated by Givoni (1998), the suggested temperature limits of acceptable conditions of still air are $18-25 \mathrm{C}^{\circ}$. During those months (April, May, September and October), the resultant temperature inside buildings is on those level in Kurdistan. The government in 2016 was able to supply up to 22 hours of electricity for residents in those months, while it dropped to maximum of 8-10 hours during winter and summer (General Directorate of Duhok Electrcitity, 2016). Because, the load on the demand for energy is more than the production size.

The reason of the high demand on heating and cooling in winter and summer is not only related to the weather conditions, but to the quality of buildings as well. Buildings in Kurdistan are not environmentally adaptable and there is a high-energy exchange between indoor and outdoor. Reasonably, buildings need to be cooled and heated for long hours in which increase the energy demand and the load on energy supply. Consequently, electricity is supplied to a lower number of dwellings that decrease the number of hours of electricity availability. The improvement of the buildings' efficiency now is crucial more than anytime. It is worth mentioning that, Kurdistan as part of the semi-arid regions, requires energy for both heating and cooling inside buildings because of the cold winter $\left(5 \mathrm{C}^{\circ}\right.$ mean low ), and hot summer $\left(40 \mathrm{C}^{\circ}\right.$ mean high). The big variation between the mean high and low, makes the adaptability of buildings to the weather harder.

However, based on the collected information from the General Directorate of Duhok electricity, the demand for energy during winter has always been larger than in summer. The difference can reach $35-45 \%$ between the both seasons because winter is longer than summer, as well as, more energy needs for domestic hot water in winter. 


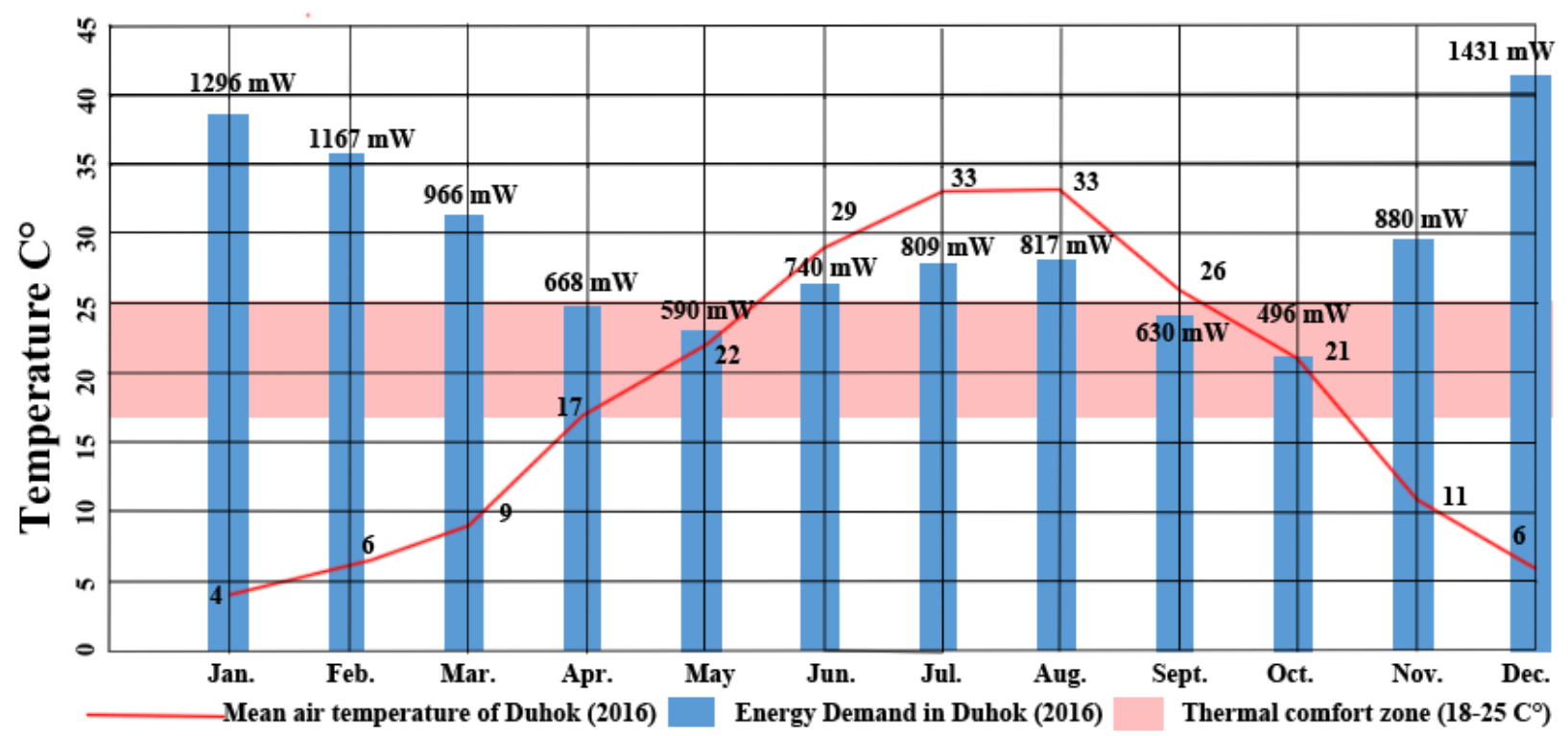

Fig (3) : Relation between energy demand and mean radiant temperature in Duhok, Iraq 2016. Energy data source:

(General Directorate of Duhok Electrcitity, 2016)

\section{ENERGY EFFICIENT BUILDING AS AN ALTERNATIVE}

A sustainable building design has become one the approached strategies nowadays in the most developed countries to overcome the issues of the high-energy consumption. The concept of energy efficient buildings relates to the use of minimum energy for achieving the desirable indoor environment (Pacheo, Ordonez, \& Martinez, 2012). A part of the concept is the strategy of sustainable heating and cooling to shrinkage the buildings' energy load (Ibid). Ekici and Aksoy (2011) stated that besides the environmental parameters, design parameters that influence on building energy requirements are the shape factor, transparent surface, building orientation, thermal-physical properties of building materials and distance between buildings. This paper has mainly focused on the strategy of building orientation, thermal properties of building material and shape factor.

\subsection{Building Orientation}

Buildings' orientation is one of the most frequent studied parameters that seeks the passive solar design of buildings. It controls over the amount of the solar radiation that receives by building. An optimum orientation allows buildings to receive maximum radiation during cold months and minimum during hot months (Givoni, 1998). Consequently, the amount of the auxiliary heating and cooling of building will reduce to a minimum size. The level of direct solar radiation on building wall depends on the azimuth in the wall which specified by the orientation angle of buildings (Mingfang, 2002). As a rule of thumb, for best living conditions (warmth in winter, coolness in summer), the longest façade of building should face south (Brown \&
Dekay, 2001). In winter, the solar angle is low allowing the southern building facades to receive maximum solar radiation. Whilst, the angle is high in summer and the heat gain reduces easily by overhangs or solar shadings. In a case study conducted by Aksoy and Inalli (2006), the relation between building energy consumption and building orientation was examined. It was concluded that an insulated building with a southern façade could consume $36 \%$ less energy than the same building but with other orientation. However, if a building have no thermal insulation layer, a maximum of only $8 \%$ of energy reduction achieved from the optimal orientation. In Kurdistan, the opportunity of changing building's orientation is limited. The city Master Planning department divides building plots to a typical design of row houses, which have a specific orientation. Building plots are divided with standard dimension of $10 * 20 \mathrm{~m}$ and have only one façade $(10 \mathrm{~m})$ facing the cardinal directions (north, south, east or west) (Kadir, 2010). Accordingly, an approximate of only $25 \%$ of buildings can face south and the rest buildings face the north, east, and west. In contrast, the east and west oriented buildings have difficulties in controlling the solar radiation. They are warmer in summer and cooler in winter than the south oriented buildings (Olgyay, 2015). As for the north oriented houses, people who are living in these houses spend more energy for heating because of the low solar gain in winter, even though, they have the advantage in summer. Based on that, reconsideration should be undertaken on the design of the row house orientations. As suggested by Olgyay (2015), a variation of $20-30^{\circ}$ from south to southeast and west is adjustable for building orientation. Hence, an 
adjustment of $20-30^{\circ}$ in the orientation of the current residential plots design could be an easy and effective strategy for decreasing power consumption in all buildings (Fig.4). It will help most future residential buildings to consume less energy, because the east and west buildings will partially face the south. As for the current buildings, regulations and passive strategies could be applied to prevent the east and west oriented houses from the high solar gain in summer through adding longitudinal shading systems on building facades. Additionally, as suggested by Heisler (1986), increasing the amount of deciduous trees that are green in summer and fall their leaves in winter could be another effective strategy.

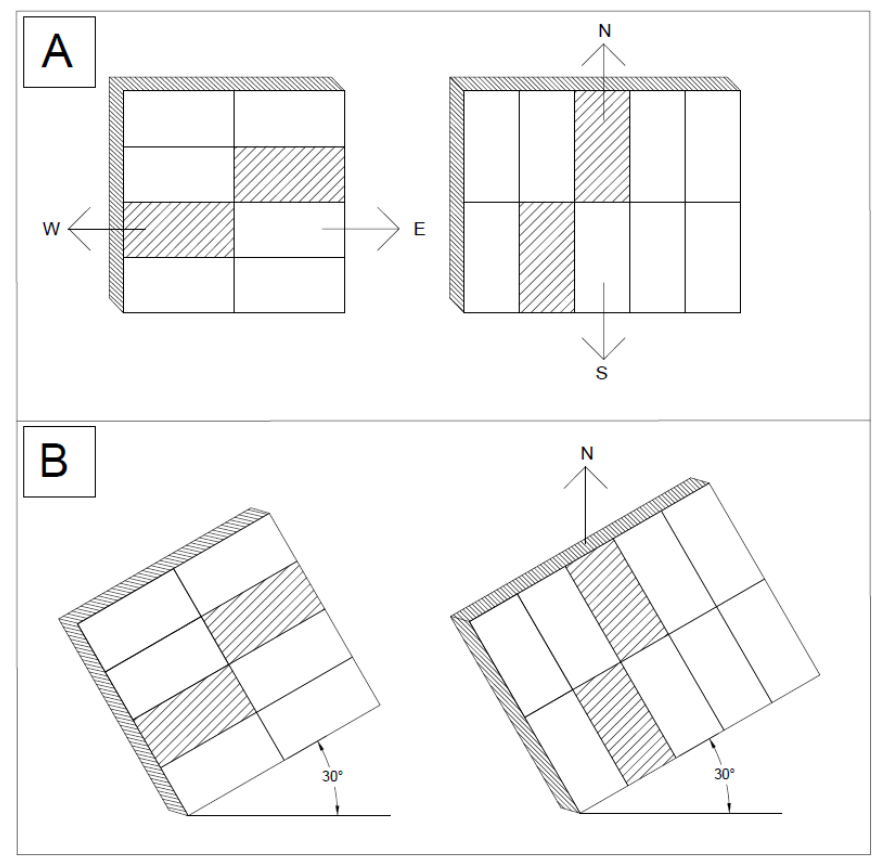

Fig (4 A) : Typical urban plots design in Kurdistan. B. Enhanced orientation of the typical urban plot's design

\subsection{Thermal Properties of Building Materials (Building U-Value)}

Building's envelop has always been an important layer when the energy efficiency of building is measured. Because, it is the connection layer between the indoor and outdoor environment. Considering the heating and cooling load, the thermal behavior of building materials is the key concept in controlling the heat transfer in winter and summer through the building envelop. It depends on the thermal resistance and conductivity of the construction materials; as well as the thickness of the envelop layer (Jankovic, 2012). Together they form the ability of the layer in reducing the thermal exchange between indoor and outdoor, which is known as Uvalue (Ibid).

$$
R-\text { value }=\frac{D}{\chi^{\prime}}, \text { U-value of wall }=\frac{1}{\sum R}
$$

When R-value is the Resistance of heat loss $\left(\mathrm{m}^{2} \cdot \mathrm{K} / \mathrm{W}\right)$, $\mathrm{D}$ is the thickness of constructional layer $(\mathrm{M})$, U-value is the measurement the of heat loss $(\mathrm{W} / \mathrm{m} 2 \mathrm{k}), \lambda$ is the thermal conductivity of material $\left(\mathrm{m}^{2} \cdot \mathrm{K} / \mathrm{W}\right)$, and $\sum R$ is the sum of the thermal resistance of all layers of the wall. The less the U-value of the building envelop, the less the heat transfer occurs between inside and outside the building. Therefore, it is always recommended that to keep in a low level (Ibid). It worth mentioning that the standard and recommended U-value varies from one country to another, since the climate zones and economic conditions highly affect on the selection of the optimum U-values. Schimschar, Boermans, Kretschmer, Offermann, and John (2016), in a report published by Ecofyes, the suggested U-values for Turkish regions that are close to the Kurdistan region of Iraq are as follows, $0.6 \mathrm{~W} / \mathrm{m}^{2} \mathrm{k}$ for walls and floors, $0.4 \mathrm{~W} / \mathrm{m}^{2} \mathrm{k}$ for roofs, and $2.4 \mathrm{~W} / \mathrm{m}^{2} \mathrm{k}$ for windows. In Kurdistan, there are no thermal regulations in building design and no considerations to the heat transfer in building construction as well. As reported by Kadir (2010), most residential buildings in Kurdistan are built with a layer of concrete blocks, finished inside with a layer of gypsum, and a layer of cement mortar or masonry stones from the outside. While the roofs are built with R.C.C slab $(15 \mathrm{~cm})$ that left abandoned from outside and finished with a layer of gypsum plastering form inside. According to the conventional calculation, the U-values for the typical walls in Kurdistan is approximately 1.96 $\mathrm{W} / \mathrm{m}^{2} \mathrm{k}$ and $2.34 \mathrm{~W} / \mathrm{m}^{2} \mathrm{k}$ for roofs.

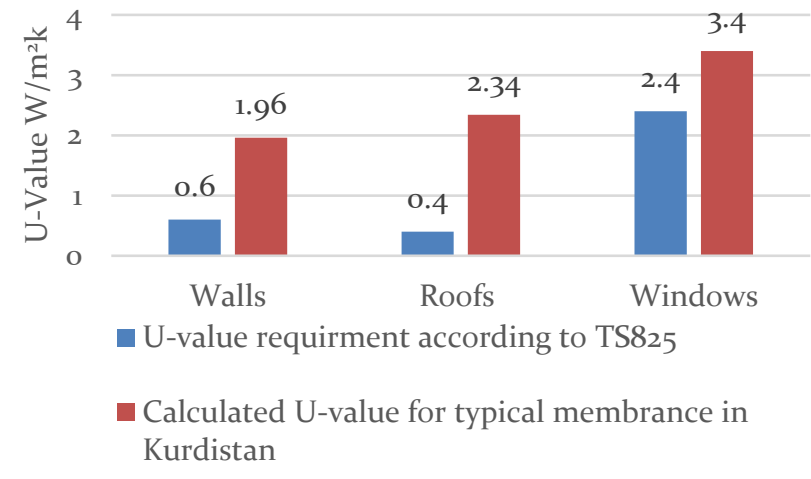

Fig (5) : Comparison between the recommended Uvalue for Turkish regions near to Kurdistan region of Iraq and calculated U-value of typical membranes in Kurdistan region

These U-values are high in comparison with the optimal aforementioned values in Turkey regions, which make the heat transfer easier in winter and summer (Fig 5). Therefore, more energy loses during the two seasons for heating and cooling to keep buildings in the thermal comfort degrees. Hence, the total energy demand grows bigger. Thermal insulation materials with a high thermal resistance are usually used as a layer of 
insulation in the building envelope. Adding a layer of $(2.5-5) \mathrm{cm}$ of these materials to the building envelope can decrease the U-value to an optimum level. Therefore, it is suggested that to be added to the existing residential buildings to decrease the energy consumption during the two seasons (Fig.6. A and B). Thermal blocks, hollow bricks, and hollow blocks also can be used instead of the solid blocks in the future expansion. These blocks have a lower thermal conductivity than the solid blocks, which would increase the energy efficiency of the future buildings in Kurdistan. These strategies could be applied as mandatory regulations for all newly constructed buildings in Kurdistan.

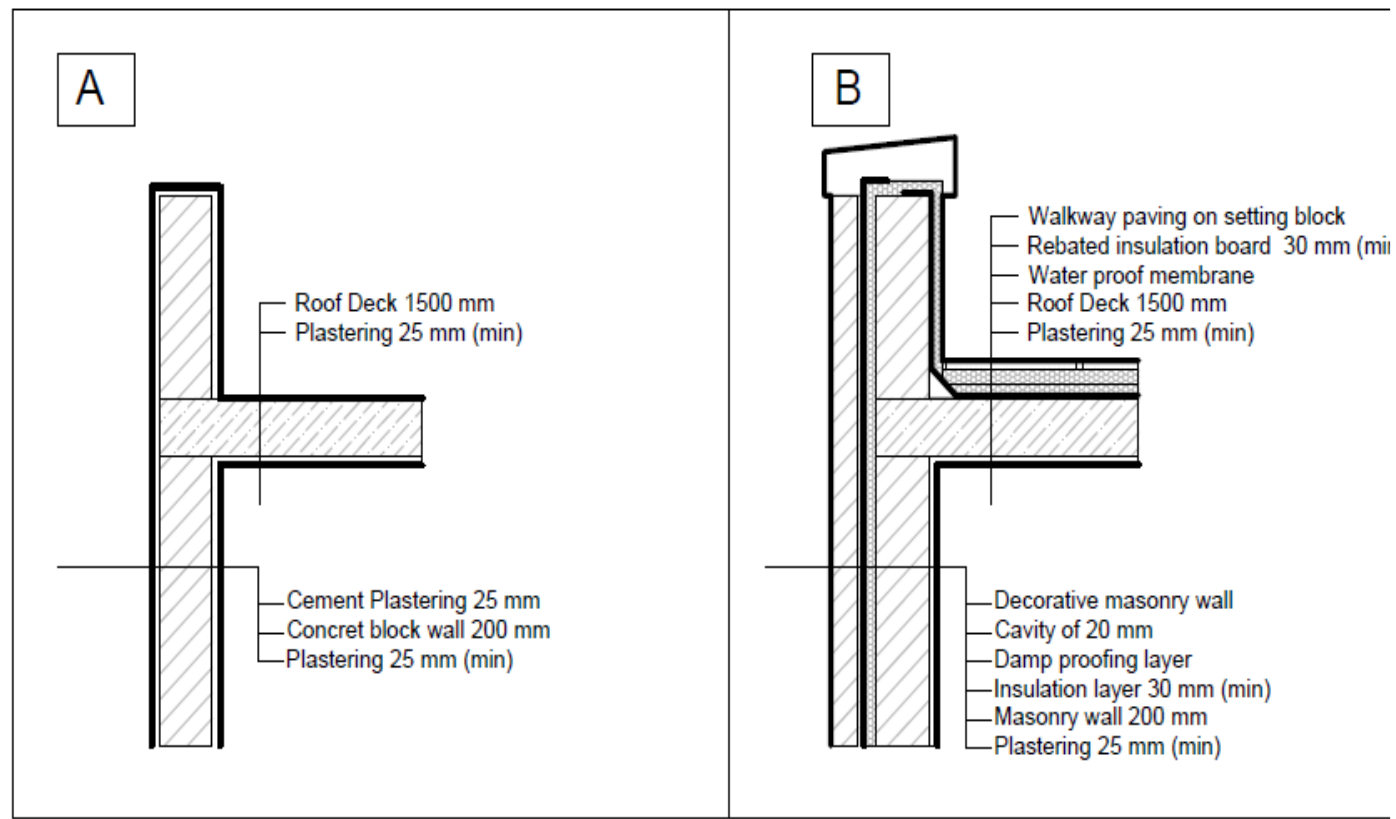

Fig (6) : A) Typical roof and wall section in Kurdistan. B) Enhancement of the typical wall and roof section adding thermal insulation

\subsection{Building Compactness ( $\mathrm{S} / \mathrm{V}$ ratio)}

The surface area to volume (S/V) ratio of building shape is considered one of the key factors for measuring the amount of heat gain and loss in buildings. Fundamentally, this ratio controls the rate of heat exchange between inside and outside of buildings; also it influences on the amount of exposure to the solar radiation (Givoni, 1998; Brown \& Dekay, 2001; Olgyay, 2015). The more compact the building shape, the smaller the exposed volume to the ambient temperature. Hence, the heat exchange between ambient air and indoor air temperature decreases (Givoni, 1998). While, if the building layout is spread out, more building surface area will expose to the outside condition; consequently, more heat gain and loss will occur. For energy efficiency, it is recommended to keep the S/V ratio to the minimum. However, this ratio contrary works with the amount of the natural daylight that enters the building (Ibid). Because, the decline of the S/V reduces the opportunity of building surfaces to the daylight. Several studies have proven that apartments needs less energy than the row and single house in temperate climates. Taleghania, Tenpierika, Dobbelsteena, and Dear (2012) have conducted a research in Netherland (temperate climates) to compare the three type of the housing styles above. They suggested that the flats due to their low $\mathrm{S} / \mathrm{V}$, consume less energy than single and row houses.

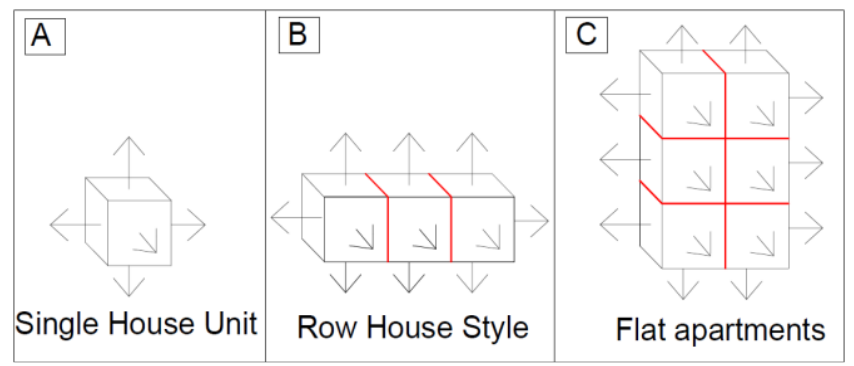

Fig (7) ; Surface-to-Volume (S/V) decreases from A-C with the compactness of the building shape

In Kurdistan the majority of residential buildings are the row house style. They have a lower S/V in comparison with semi-detached or single houses. However, they have a higher $\mathrm{S} / \mathrm{V}$, comparing with the apartment flats, since the flats are attached to other flat units from top and bottom. Eventually, the number of the surfaces that expose to the outside conditions decreases. It should be bear in mind that in addition to their higher S/V ratio, the row houses are not thermally insulated from the roof as it was mentioned before. Therefore, they expose to a high heat gain during 
summer; as well as, the energy escapes from the top roof of buildings easily in the winter (see Fig. 8).

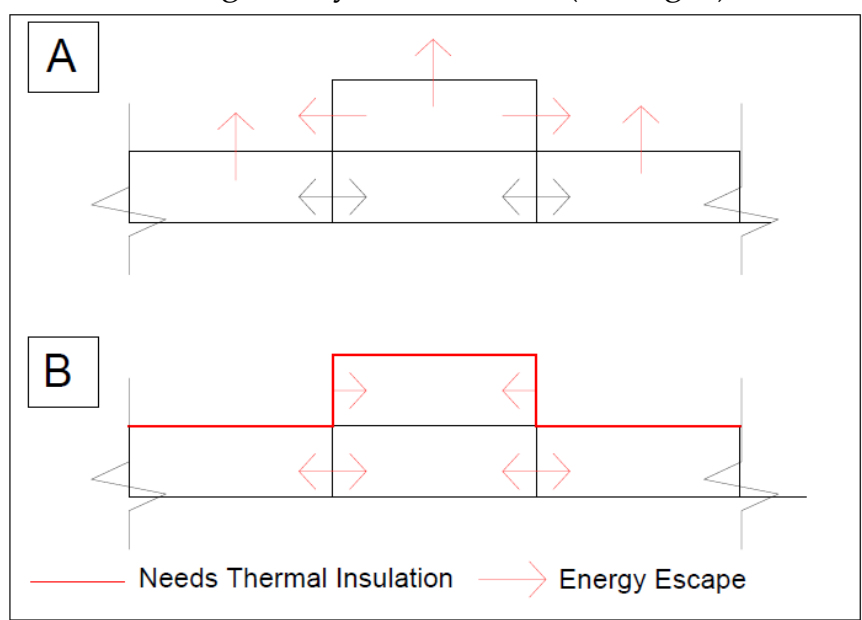

Fig (8) : A) Typical section through row houses shows energy escape due to poor insulation

B) Improvement of the typical row house trough adding a layer of thermal insulation

\section{CASE STUDY}

A case study was conducted in order to measure the influence of the mentioned factors on the power consumption in Kurdistan. Energy consumption of some buildings has been compared together that alters with the U-value, orientation and the S/V. This suggested an insight on how these factors vary the consumption of energy in buildings and consequently affect on the overall energy supply of cities. The case was conducted in Duhok city in the Kurdistan region of Iraq. Apparently, these are not the only factors that effect on the energy consumption of buildings. According to Baker and Steemers (2000), factors that affect on the consumption of energy in buildings are the climate, urban contest, building design, system and occupant. The focus of the study is only on the design factors which are the U-value, orientation and the S/V. Therefore, it was deemed essential to keep the other factors on the constant condition, because any variation in the other factors will deviate the measurements of the design factors (the U-value, orientation and the S/V).

\subsection{Data collection}

Two families have been selected in Duhok city for this case study. Their energy data has been compared in two cases. First, when they were living in an apartment. Second, after they moved to a single row house in the city. The purpose of selecting a case like that is based on a number of reasons. Primarily, the two flats differ from the row houses in the design factors. Both flats have at least a façade with the optimum orientation (South direction). Both of them have been insulated with a layer of $4 \mathrm{~cm}$ of thermal insulation which means they have less U-Value than the row house. Further, the flats have a less $\mathrm{S} / \mathrm{V}$, since they are units in the apartment buildings which are covered from the roof and floor by other flats. Table 1 shows the variations between the selected flats and the row house units based on the taken data and measurements. In addition to that, the two families in both cases (living in the flat and the row house) had the same lifestyle, family size, occupant behavior, and number of appliances. Hence, these factors can be specified as constant, which they will not affect highly on further power consumption in the case of a specific family that lived in both cases (flat and row house). Therefore, any variation in the energy consumption will refer to the building design quality.

TABLE (1) : Design Variation (Orientation, S/V, and U-value) of the Selected Samples

\begin{tabular}{|c|c|c|c|c|c|c|}
\hline & Type & Code & $\begin{array}{c}\text { Orientati } \\
\text { on }\end{array}$ & $\mathrm{S} / \mathrm{V}$ & $\begin{array}{l}\text { Wall U- } \\
\text { Value }\end{array}$ & $\begin{array}{c}\text { Roof U- } \\
\text { Value }\end{array}$ \\
\hline \multirow{2}{*}{ 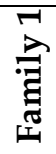 } & Flat & FA1 & $\begin{array}{c}\text { South- } \\
\text { East }\end{array}$ & 0.18 & 0.79 & ---------- \\
\hline & House & FA2 & East & 0.49 & 1.96 & 2.34 \\
\hline \multirow{2}{*}{ 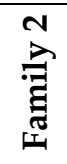 } & Flat & FB1 & $\begin{array}{l}\text { South- } \\
\text { West }\end{array}$ & 0.18 & 0.78 & ----_---- \\
\hline & House & FB2 & $\begin{array}{l}\text { North- } \\
\text { West }\end{array}$ & 0.38 & 0.79 & 2.34 \\
\hline
\end{tabular}




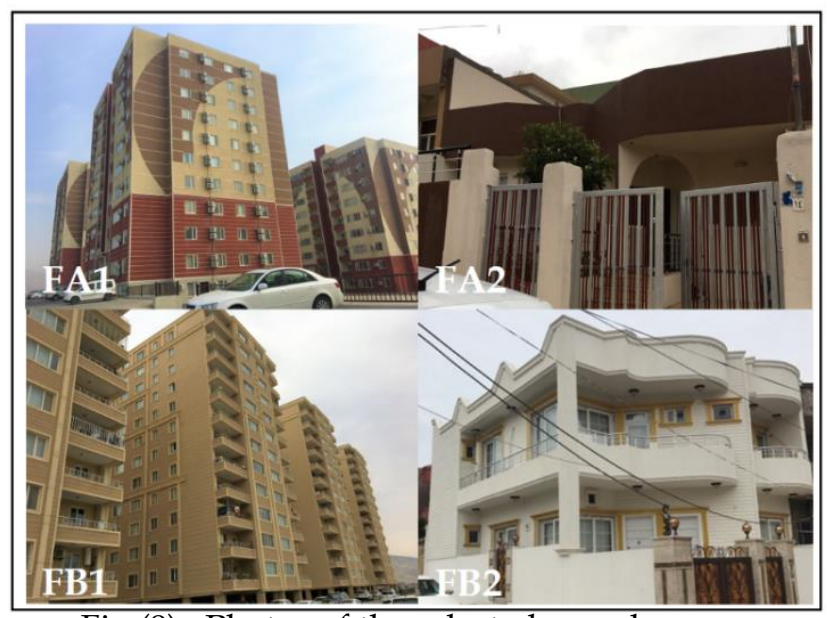

Fig (9) : Photos of the selected samples
Moreover, in order to fix the climate variation, the energy data for the comparison was of 3-4 months. As well as, from the same period, since the climate does not change vastly in the same period every year. For instance, the collected energy data of the family 2 (see TABLE 2), was for nearly four months. From (1/9/2016) until $(17 / 12 / 2016)$ when they were living in the flat house, and the same period after they moved to the single house in 2017. The difference in weather is small for a specific period each year, thus, the energy data can be compared for the family in the two different building situations.

TABLE (2) : Timetable of the Energy Data Collection of the samples

\begin{tabular}{|c|c|c|c|c|c|}
\hline & Type & Code & Start date & End date & $\begin{array}{c}\text { Number } \\
\text { of days }\end{array}$ \\
\hline \multirow{2}{*}{ 窟 } & Flat & FA1 & $3 / 8 / 2016$ & $8 / 11 / 2016$ & 95 \\
\cline { 2 - 6 } & House & FA2 & $3 / 8 / 2017$ & $8 / 11 / 2017$ & 95 \\
\hline \multirow{2}{*}{ 突 } & Flat & FB1 & $1 / 9 / 2016$ & $17 / 12 / 2016$ & 107 \\
\cline { 2 - 6 } & House & FB2 & $1 / 9 / 2017$ & $17 / 12 / 2017$ & 107 \\
\hline
\end{tabular}

\subsection{Data results}

Based on the results, there is a considerable variation in power consumption for both households in both conditions. Family 1 increased their energy consumption by $21 \%$ (from 13.69 to $16.96 \mathrm{kWh} / \mathrm{m}^{2}$ ) after they have moved to a house with the higher U-value, higher S/V, and less optimal orientation. As for the family 2, the increment was about 29\% (from 11.94 to $16.79 \mathrm{kWh} / \mathrm{m}^{2}$ ) (see Fig.10).

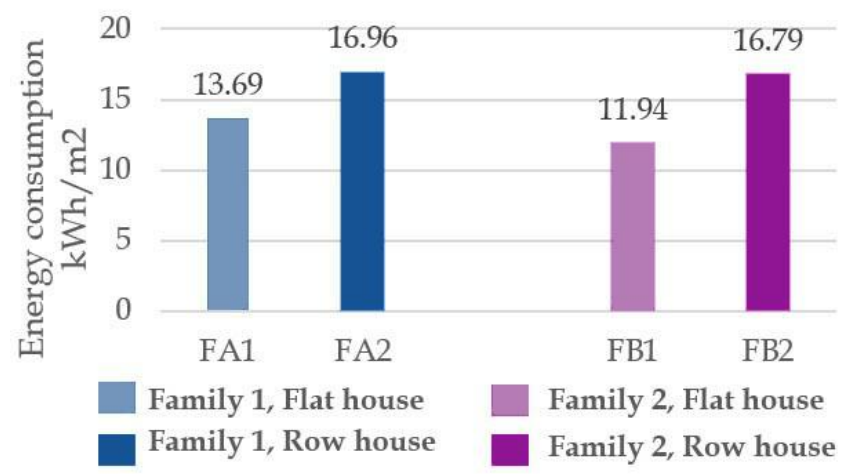

Fig (10) : Energy consumption $\left(\mathrm{kWh} / \mathrm{m}^{2}\right)$ for the selected samples

Accordingly, the factors that have been mentioned previously have a major influence over the high variation in energy consumption. Both flats (FA1 and FB1) have the southern orientation that can receive the maximum energy radiation in winter and minimum in summer. Further, they have the minimum $S / V$ in comparison with the other types (FA2 and FB2) as shown in TABLE 1; as well as, both flats have been built with materials that have efficient thermal properties such as hollow bricks and thermal hollow blocks (See appendix). Moreover, both flats have been covered by a layer of $5 \mathrm{~cm}$ of thermal insulation, which gives them a lower U-value in comparison to single houses as shown in the table.

\section{CONCLUSION}

This paper has sought alternatives for decreasing the demand on energy consumption in Kurdistan through architectural means. The research focused on the heating and cooling load reduction since it consumes more than half of the energy in Kurdistan. Specially the heating load, which is $35-45 \%$ higher than cooling load in some cities like in Duhok. The study suggests that building orientation, thermal properties of material and the building compactness can play a key role on the reduction of the demand for energy. Most building's designers in Kurdistan do not consider these factors. The research pointed out that for decreasing the total demand on energy, it is suggested to put regulations on newly built up constructions in Kurdistan. The new design regulations should enable housing sector to perform better in terms of heating and cooling. The new thermal regulation should focus on minimizing 
Buildings U-Value, and surface-to-volume ratio of buildings, as well as enhancing building's solar gain by having the optimum orientation. A case study was conducted on some existing buildings in Duhok to observe the impact of the mentioned factors on the building energy demand. A variation of $21-29 \%$ of energy consumption was found between buildings have taken these factors in to their design and construction measurements.

\section{APPINDEX}

U-value calculation of the samples' walls and roofs.

\begin{tabular}{|c|c|c|c|}
\hline $\begin{array}{l}\text { FB2 Wall U- } \\
\text { value }\end{array}$ & & & \\
\hline Material & $\begin{array}{c}\text { Thickness } \\
\text { m }\end{array}$ & $\begin{array}{c}\lambda- \\
\text { value }\end{array}$ & R-value \\
\hline $\begin{array}{l}\text { external } \\
\text { Surface } \\
\text { Resistance }\end{array}$ & 0 & 0 & 0.04 \\
\hline Foam & 0.03 & 0.038 & 0.78 \\
\hline $\begin{array}{c}\text { concert } \\
\text { block }\end{array}$ & 0.2 & 1.13 & 0.176 \\
\hline $\begin{array}{l}\text { Gypsum } \\
\text { plastering }\end{array}$ & 0.025 & 0.22 & 0.11 \\
\hline Internal & 0 & 0 & 0.13 \\
\hline & \multicolumn{2}{|c|}{ U-Value of the wall } & 0.79 \\
\hline \multicolumn{4}{|l|}{$\begin{array}{c}\text { FB1 Wall U- } \\
\text { value }\end{array}$} \\
\hline Material & $\begin{array}{l}\text { Thickness } \\
(\mathrm{m})\end{array}$ & $\begin{array}{c}\lambda- \\
\text { value }\end{array}$ & R-value \\
\hline $\begin{array}{c}\text { external } \\
\text { Surface } \\
\text { Resistance }\end{array}$ & 0 & 0 & 0.04 \\
\hline Foam & 0.03 & 0.038 & 0.78 \\
\hline Brick & 0.12 & 0.62 & 0.19 \\
\hline $\begin{array}{l}\text { Gypsum } \\
\text { plastering }\end{array}$ & 0.025 & 0.22 & 0.11 \\
\hline $\begin{array}{l}\text { Internal } \\
\text { Surface } \\
\text { Resistance }\end{array}$ & 0 & 0 & 0.13 \\
\hline & \multicolumn{2}{|c|}{ U-Value of the wall } & 0.78 \\
\hline \multicolumn{4}{|l|}{$\begin{array}{c}\text { FA2 Wall U- } \\
\text { value }\end{array}$} \\
\hline Material & $\begin{array}{c}\text { Thickness } \\
\text { m }\end{array}$ & $\begin{array}{c}\lambda- \\
\text { value }\end{array}$ & R-value \\
\hline $\begin{array}{c}\text { external } \\
\text { Surface } \\
\text { Resistance }\end{array}$ & 0 & 0 & 0.04 \\
\hline $\begin{array}{c}\text { External } \\
\text { Sand/cemen }\end{array}$ & 0.025 & 1 & 0.025 \\
\hline
\end{tabular}

\begin{tabular}{|c|c|c|c|}
\hline trender & 0.2 & 1 & 0.2 \\
\hline $\begin{array}{c}\text { concert } \\
\text { block }\end{array}$ & 0.025 & 0.22 & 0.11 \\
\hline $\begin{array}{c}\text { Gypsum } \\
\text { plastering }\end{array}$ & 0 & 0 & 0.13 \\
\hline $\begin{array}{c}\text { Internal } \\
\text { Surface } \\
\text { Resistance }\end{array}$ & \multicolumn{2}{|c|}{ U-Value of the wall } & 1.96 \\
\hline
\end{tabular}

\begin{tabular}{|c|c|c|c|}
\hline $\begin{array}{c}\text { FA1 Wall U- } \\
\text { value }\end{array}$ & \multicolumn{3}{|l}{} \\
\hline Material & $\begin{array}{c}\text { Thickness } \\
\mathrm{m}\end{array}$ & $\begin{array}{c}\lambda \text { - } \\
\text { value }\end{array}$ & R-value \\
\hline $\begin{array}{c}\text { external } \\
\text { Surface } \\
\text { Resistance }\end{array}$ & 0 & 0 & 0.04 \\
\hline Foam & 0.03 & 0.038 & 0.78 \\
\hline $\begin{array}{c}\text { hollow } \\
\text { concert } \\
\text { block }\end{array}$ & 0.15 & 0.8 & 0.18 \\
\hline $\begin{array}{c}\text { Gypsum } \\
\text { plastering }\end{array}$ & 0.025 & 0.22 & 0.113 \\
\hline $\begin{array}{c}\text { Internal } \\
\text { Surface } \\
\text { Resistance }\end{array}$ & 0 & 0 & 0.13 \\
\hline & U-Value of the wall & 0.79 \\
\hline & \multicolumn{2}{|c|}{} \\
\hline
\end{tabular}

\begin{tabular}{|c|c|c|c|}
\hline $\begin{array}{c}\text { FA2, FB2 } \\
\text { roof U-value }\end{array}$ & & & \\
\hline Material & $\begin{array}{c}\text { Thickness } \\
\text { m }\end{array}$ & $\begin{array}{c}\lambda- \\
\text { value }\end{array}$ & R-value \\
\hline $\begin{array}{c}\text { external } \\
\text { Surface } \\
\text { Resistance } \\
\end{array}$ & 0 & 0 & 0.04 \\
\hline Concert Slab & 0.2 & 1.4 & 0.14 \\
\hline $\begin{array}{l}\text { Gypsum } \\
\text { plastering }\end{array}$ & 0.025 & 0.22 & 0.11 \\
\hline \multirow[t]{2}{*}{$\begin{array}{c}\text { Internal } \\
\text { Surface } \\
\text { Resistance } \\
\end{array}$} & 0 & 0 & 0.13 \\
\hline & \multicolumn{2}{|c|}{ U-Value of the roof } & 2.34 \\
\hline
\end{tabular}

\section{BIBLIOGRAPHY}

1. Aksoy, U., \& Inalli, M. (2006), Impacts of some building passive design parameters, Building and Environment, 41:1742-54.

2. Baker, N., \& Steemers, K. (2000), Energy and Environment in Architecture. London : E\&FN Spon.

3. Brown, G., \& Dekay, M. (2001), Sun, Wind \& Light: Architectural Design Strategies (2nd Edition ed.), New 
York: John Wiley \& Sons.

4. Ekici, B., \& Aksoy, U. (2011), prediction of building energy needs in early stage of design. Expert Systems with Applications, 38:5352-8.

5. General Directorate of Duhok Electrcitity. (2016), Ronahi. Duhok: General Directorate of Duhok Electrcitity.

6. Givoni, B. (1998), Climate consideration in Building and Urban Environment. Canada: John Wiley \& Sons.

7. Heisler, G. M. (1986), Effects of individual trees on the solar radiation climate of small buildings, 9 (1986) 337-359 : Urban Ecology.

8. Jankovic, L. (2012), Designing Zero Carbon Building Using Dynramic Simulation Methods, New York: Routledge.

9. Kadir, S. G. (2010), Scientifically Building Research for Kurdistan-Region (First Ediiton ed.), Erbil: Tafseer. 10. Kurdistan Ministry of Electricity, (2014), Energy \& Energy Conservation. Retrieved December 27, 2015, from

http://www.krgmoel.org/Wenekan_KS/29671312015_ 14-12-2014.pdf

11. Mingfang , T. (2002), Solar control for buildings, Building and Environment, 37:659-64.

12. Olgyay, V. (2015), Design with Climate, Oxfordshire: Princeton University Press.

13. Pacheo, R., Ordonez, J., \& Martinez, G. (2012), Energy efficient design of building: A review, Renewable and Sustainable Energy Review , 3560-3573. 14. Schimschar, S., Boermans, T., Kretschmer, D., Offermann, M., \& John, A. (2016), U-Value maps Turkey : Applying the comparative methodology framework for cost-optimality in the context of the EPBD. Kolin : Ecofyes.

15. Sorrell, S. (2015). Reducing energy demand: A review of issues,challenges and approaches. Renewable and Sustainable Energy Reviews, 47 (2015) 74-82.

16. Taleghania, M., Tenpierika, M., Dobbelsteena, A. v., \& Dear, R. (2012), Energy use impact of and thermal comfort in different urban block types in the Netherlands. Energy and Buildings , 166-175. 